\title{
MODELLING OF NONLINEAR THERMODIFFUSION FOR A SPHERICALLY SYMMETRIC CASE
}

\author{
Arvydas J. Janavičius ${ }^{\dagger}$, DSigita Turskiené* \\ Institute of Regional Development, Šiauliai University, Lithuania \\ P. Višinskio st. 25, LT-76351 \\ *Corresponding Author: turskienes@gmail.com \\ ${ }^{\dagger}$ E-mail: AYanavy@gmail.com
}

Received December4, 2020; revised February 13, 2021, accepted February 15, 2021

The paper discusses the properties of the nonlinear thermodiffusion equation corresponding to the heat transfer processes occurring with a finite velocity in gas from a high intensity source. In the previous papers A. J. Janavičius proposed the nonlinear diffusion equation which provided a more exact description of impurities diffusion by fast moving vacancies generated by X-rays in Si crystals. This is similar to the heat transfer in gas with constant pressure by molecules carrying a greater average kinetic energy based on the nonlinear thermodiffusion of gas molecules from hot regions to the coldest ones with a finite velocity by random Brownian motions. Heat transfer in gas must be compatible with the Maxwell distribution function. Heat transfer in gas described by using nonlinear thermodiffusion equation with heat transfer coefficients directly proportional to temperature $T$. The solution of the thermodiffusion equation in gas was obtained by using similarity variables. The equation is solved by separating the linear part of the equation that coincides with Fick's second law. The obtained results coincide with Ya.B. Zeldovich's previously published solutions of nonlinear equations by changing the respective coefficients.

KEYWORDS: nonlinear thermodiffusion, high intensity source, similarity solution, temperature profiles, spherically symmetric case

In the previous papers we have discussed the nonlinear diffusion of impurities in semiconductors [1-2], nonlinear thermodiffusion in gas [2-3] and heat transfer in metals by electrons [4] using mathematical methods of similarity variables [1] for the solution of the nonlinear equation. The obtained results are important for engineering calculations of heat transfer in gas at constant pressure.

It is assumed that the process of thermal transmittance in gas is similar to nonlinear diffusion process of impurities described as Brownian movement of atoms in solids spreading with a finite velocity. Heat transfer can be described by using a modified theory of nonlinear diffusion in solids [1]. In this case the frequency of the jumps of diffusing molecules [2] depends upon the coordinates and changing molecules concentration $n$ and temperature $T$ according law of ideal gas defining pressure $p=n k T$.

The coefficient of thermal conductivity of gas can be expressed in the following way [2], [6]

$$
K=\frac{1}{3} \lambda \bar{v} c_{v} \rho=D_{w}(T) c_{v} \rho=\frac{k \bar{v}}{2 \sqrt{2} \pi d^{2}}, \lambda=\frac{1}{\sqrt{2} \pi d^{2} n}, \bar{v}=\sqrt{\frac{8 R T}{\pi \mu}} .
$$

Here $\lambda$ is the mean value of a free path of diffusing molecules, $\bar{v}$ - the mean velocities of molecular movement, $c_{v}$ - the molar heat capacity at constant volume, $\rho$ - the density of gas, $n$ - the number of molecules per unit volume, $k$ - Boltzmann constant, $T$ - temperature of gas, $\mu$ - molar mass, $R$ - gas constant, $d$ - the distance between centers of the diffusing molecules of the gas, $D_{w}(T)$ - the thermodiffusion function of impurities in gas for the isobaric process.

The equation of thermodiffusion in gases can be obtained with the coefficient $D_{w}(T)$, which is proportional to the temperature [7] of gas. Similarly, as in the case of nonlinear diffusion in crystal silicon [1] by using (1), the coefficient $D_{w}(T)$ can be introduced

$$
D_{W}(T)=\frac{K(T)}{\rho \cdot c_{p}}=\frac{1}{3} \frac{c_{v}}{c_{p}} \lambda \bar{v}=\frac{1}{3} \frac{c_{v}}{c_{p}} \vec{v} \frac{k T_{S}}{\sqrt{2} \pi d^{2} p} \frac{T(r, t)}{T_{s}}=D_{w s} \frac{T(r, t)}{T_{S}}
$$

The constant pressure $p=n(r, t) k T(r, t)=n_{S}(r, t) k T_{S}(r, t)$ at slow impurities transmission in gas with decreasing temperature $T(r, t)$ is compensated by increasing the concentration $n(r, t)$ of impurities in gases with heating from the spherical source of temperature $T_{S}$.

Here $D_{w s}$ is the thermodiffusion proportionality constant for the nonlinear thermodiffusion function $D_{W}(T)$ for the specific heat capacity $c_{p}$ of gas at the constant pressure $p, K_{S}$ - the coefficient of thermal conductivity at source. From the theory of Brownian motion follows that the diffusion velocity and the maximum penetration depth of impurity atoms 
and heat transfer velocity must be finite. Consequently [1], the thermodiffusion coefficient $D_{W}(r, t)$, defined by thermodiffusion constant at source $D_{w s}$, is directly proportional to the temperature

$$
D_{W}(T)=D_{W}(r, t)=\frac{D_{w s}}{T_{S}} T(r, t)=D_{w n} T(r, t), D_{w s}=D_{w n} T_{S}
$$

which requires that the first Fick law must be improved by introducing the heat flux [1], [2] according the radial direction

$$
j=-D_{w n} T(r, t) \frac{T(r+\Delta r, t)-T(r, t)}{\Delta r} \approx-D_{w n} T \frac{d T}{d r}
$$

with the finite length $\Delta r$ of the jumps with the finite velocity [1] of diffusing particles. It can be assumed that the jump length of the diffusing atoms or molecules from one equilibrium position to another in solids or fluids has the definite value $L$. particles

In gases $L$ may be the average free path of diffusing particles. From the conservation the number of diffusing

$$
\oint_{S} D_{W} \cdot \operatorname{grad}(T) d S=\int_{V} \frac{\partial T}{\partial t} d V, D_{W}=D_{w n} T(x, y, z, t)
$$

and the theorem of Gauss' [6]

$$
\int_{V} \operatorname{div}\left(D_{W} \cdot \operatorname{grad}(T)\right) d V=\int_{V} \frac{\partial T}{\partial t} d V
$$

the following nonlinear thermodiffusion equation is obtained

$$
\operatorname{div}\left(D_{W} \operatorname{grad}(T)\right)=\frac{\partial}{\partial x}\left(D_{W} \frac{\partial T}{\partial x}\right)+\frac{\partial}{\partial y}\left(D_{W} \frac{\partial T}{\partial y}\right)+\frac{\partial}{\partial z}\left(D_{W} \frac{\partial T}{\partial z}\right)=\frac{\partial T}{\partial t} .
$$

By using the nonlinear diffusion equation [5], [6] the following thermodiffusion equation in spherical coordinates can be obtained

$$
\frac{\partial T}{\partial t}=-\operatorname{div}\left(-D_{W}(T) \operatorname{grad}(T)\right), j_{p}=-D_{W}(T) \frac{\partial T}{\partial r}=-D_{w n} T \frac{\partial T}{\partial r} .
$$

The equation (6) for temperature $T(r, t), 0 \leq r \leq r_{0}, 0 \leq t \leq t_{0}$ can be rewritten in the spherical case

$$
\frac{\partial T}{\partial t}=\frac{D_{w n}}{T_{S} r^{2}}\left(\frac{\partial}{\partial r}\left(\operatorname{Tr}^{2} \frac{\partial T}{\partial r}\right)\right)=\frac{D_{w n}}{T_{S}}\left(T \frac{\partial^{2} T}{\partial r^{2}}+\frac{2}{r} T \frac{\partial T}{\partial r}+\left(\frac{\partial T}{\partial r}\right)^{2}\right),
$$

which mathematically coincides with the nonlinear diffusion equation [2].

The numerical calculations provided in [2] give the dependence $n(r, t)$ as a straight line in the region $0 \leq r \leq r_{0}$, $0 \leq t \leq t_{0}$. The temperature $T(r, t)$ dependence was obtained in a similar way [7].

The jump of hotter molecules or particles of impurities with a greater kinetic energy in the region $r+\Delta r$ with lower temperature is only possible if exists hotter at the point $r$.

This requirement is equivalent to the approval that thermodiffusion and diffusion must occur with finite value jumps and velocities. This is very important in defining coefficients of thermal conductivity [3], [7] and diffusion [1], [2].

The nonlinear heat conduction equation [8] presented for one dimensional case

$$
\frac{\partial E}{\partial t}=\frac{\partial}{\partial x}\left(k_{e}(E) \frac{\partial E}{\partial x}\right),
$$

using energy density $E$, which cannot be directly measured, is not perspective viable as equation (9) for temperature $T(r, t)$, which can be measured directly for calculation thermal conductivity [9].

The aim of the article is to get the nonlinear equation describing the flow of atoms and molecules in gases by the thermodiffusion for a spherically symmetric case and to find its approximate analytical solution.

THE NONLINEAR THERMODIFFUSION EQUATION FOR A SPHERICALLY SYMMETRIC CASE

The solution of (9) can be obtained by introducing similarity variable [5] $\xi$ and function $f(\xi)$

$$
T(\xi)=T_{S} f(\xi), \quad \xi=\frac{r}{\sqrt{D_{w n} T_{S} \cdot t}}=\frac{r}{\sqrt{D_{w s} t}},
$$




$$
0 \leq \xi \leq \xi_{0}, 0 \leq r \leq r_{0}, \quad r_{0}=\xi_{0} \sqrt{D_{w n} T_{S} \cdot t}=\xi_{0} \sqrt{D_{w s} t},
$$

which depends on the thermodiffusion constant $D_{w S}$ at source with temperature $T_{S}$. By substituting (11) into (9) the following nonlinear differential equation can be obtained

$$
f \frac{\partial^{2}}{\partial \xi^{2}} f+\frac{2}{\xi} f \frac{\partial f}{\partial \xi}+\frac{1}{2} \xi f \frac{\partial f}{\partial \xi}+\left(\frac{\partial f}{\partial \xi}\right)^{2}-\frac{1}{2} \xi f \frac{\partial f}{\partial \xi}+\frac{1}{2} \xi \frac{\partial f}{\partial \xi}=0 .
$$

The nonlinear equation (12) can be solved approximately by separating first three terms like the linear equation of hot molecules diffusion [2] can occur with the different lengths $\Delta r$ of the some average frequency of jumps as at linear heat transmittance approach

$$
f_{l}\left(\frac{\partial^{2} f_{l}}{\partial \xi^{2}}+\frac{2}{\xi} \frac{\partial f_{l}}{\partial \xi}+\frac{1}{2} \xi \frac{\partial f_{l}}{\partial \xi}\right) \approx 0,\left(\frac{\partial^{2} f_{l}}{\partial \xi^{2}}+\frac{2}{\xi} \frac{\partial f_{l}}{\partial \xi}+\frac{1}{2} \xi \frac{\partial f_{l}}{\partial \xi}\right) \approx 0 .
$$

The part of nonlinear equation (12) is transformed to linear (13) and obtained the following expression representing thermodiffusion only by nonlinear processes

$$
\left(\frac{\partial f}{\partial \xi}\right)^{2}-\frac{1}{2} \xi \cdot f_{l} \frac{\partial f_{l}}{\partial \xi}+\frac{1}{2} \xi \frac{\partial f}{\partial \xi}=0, \frac{\partial f}{\partial \xi}-\frac{1}{2} \xi \cdot f_{l}+\frac{1}{2} \xi=0 .
$$

The first [2] and the third terms in (14) represent a nonlinear diffusion or thermodiffusion. The second term in (14) represents the connection with linear thermodiffusion (13) and nonlinear equation (14) by introducing the term $P(\xi)=\frac{1}{2} \xi \cdot f_{l}$, which will be demonstrated below gets small numerical values in the region $0 \leq \xi \leq 2$.

\section{APPROXIMATE ANALYTICAL SOLUTION}

The term $P(\xi)=\frac{1}{2} \xi \cdot f_{l}$ of nonlinear equation (14) can be excluded. Thus, a simplified equation is obtained

$$
\frac{\partial f}{\partial \xi}+\frac{1}{2} \xi=0, \quad \frac{\partial f}{\partial \xi} \neq 0
$$

The equation (15) is solved for the source point temperature $T_{S}$ and environment temperature $T_{e}$

$$
\begin{gathered}
f(\xi)=1-\frac{1}{4} \xi^{2}, T(\xi)=T_{S} f(\xi), 0 \leq \xi \leq \xi_{e}, T_{e}=T_{S}\left(1-\frac{1}{4} \xi_{e}^{2}\right), \\
\xi_{e}^{2}=4 \frac{T_{S}-T_{e}}{T_{S}}
\end{gathered}
$$

by satisfying the boundary conditions for the maximum distance $r_{e}$ of heat penetration

$$
f\left(\xi_{e}\right)=0, \xi_{e}=\frac{r_{e}}{\sqrt{D_{w s} t}}, r_{e}=2 \sqrt{D_{w s} t} \sqrt{\frac{T_{S}-T_{e}}{T_{S}}},
$$

and by satisfying the boundary condition for temperature $T_{S}$ at the source point $r=0, \xi=0$

$$
f(0)=1, T(0)=T_{S} f(0)=T_{S} .
$$

The solution of the linear thermodiffusion equation (13) can by expressed [2] by similarity variables

$$
F(\xi)=\frac{T(\xi)}{T_{S}}=\frac{\Delta \xi}{\xi} \operatorname{erfc}\left(\frac{\xi-\Delta \xi}{2}\right)
$$

where the radius of source is $\Delta \xi$.

The nonlinear thermodiffusion equation (14)

$$
\frac{\partial f_{n}}{\partial \xi}-\frac{1}{2} \xi \cdot f_{n}+\frac{1}{2} \xi=0
$$


can be solved analytically by introducing a new variable

$$
\begin{gathered}
z=\xi-\xi_{e}, \xi=z+\xi_{e}, \\
\frac{\partial f_{n}}{\partial z}-\frac{1}{2}\left(z+\xi_{e}\right) f_{n}+\frac{1}{2}\left(z+\xi_{e}\right)=0
\end{gathered}
$$

The equation (21) can be modified to the following form

$$
\frac{1}{1-f_{n}} \frac{\partial\left(1-f_{n}\right)}{\partial z}=\frac{1}{2}\left(z+\xi_{e}\right)
$$

which is easy to integrate

$$
f_{n}=1-C \cdot \exp \left[0.25 z^{2}+0.5 \xi_{e} z\right]
$$

The obtained solution of the equation must satisfy the boundary condition for maximum heat penetration depth

$$
f_{n}(0)=0, \quad z=0, \xi=\xi_{e}=2, C=1 .
$$

For the heat penetration from the point source a multiplier for the obtained solution of the equation must be introduced

$$
f_{n}(z)=\frac{e}{e-1}\left(1-\exp \left(0.25 z^{2}+0.5 \cdot \xi_{e} \cdot z\right)\right), \frac{2.7183}{2.7183-1}=1.582 .
$$

The comparison of solutions (Table) $f_{n}(\xi)$ of nonlinear thermodiffusion equation (25) and $f(\xi)$ of simplified equation (16) shows the coincidence of both numerical solutions which depend on similarity variables $\xi$.

Table.

\begin{tabular}{|c|c|c|c|c|c|}
\hline$\xi$ & 0 & 0.5 & 1 & 1.5 & 2 \\
\hline$f_{n}(\xi)$ & 1 & 0.9624 & 0.8347 & 0.5606 & 0 \\
\hline$f(\xi)$ & 1 & 0.9844 & 0.7500 & 0.5625 & 0 \\
\hline
\end{tabular}

RESULTS AND DISCUSSION

The nonlinear diffusion equation is derived [10] by taking into account the local variations of impurities temperature in the solvent within a mechanism of diffusion driven by random impurities particles collisions with solvent molecules of density at average frequency

$$
v(x, y, z, t)=\sigma \cdot N(x, y, z, t) \cdot u \cdot \sqrt{2}
$$

and relative velocity (1) $u \sqrt{2}=v \sqrt{2}$ with solvent molecules of density $N$. Here $\sigma$ is the collision cross-section of diffusing particles. In real thermodiffusion process the collisions frequency depends not only on the distribution $N(x, y, z, t)$ but also on the distribution of impurities or hot molecules with velocities [6] as well as on temperature.

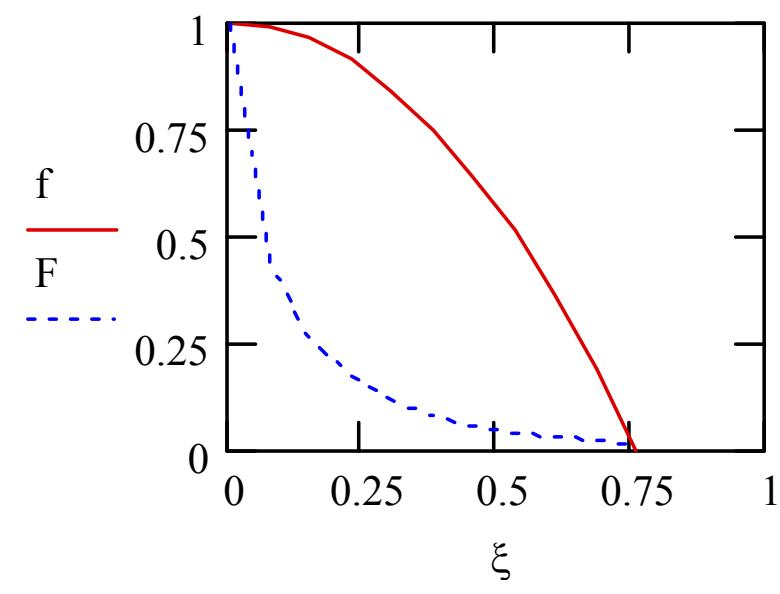

Figure 1. Profiles of nonlinear (16) $f(\xi)=\frac{T}{T_{S}}$ and linear (19) $F(\xi)$ solutions of equation for the point source with temperature $T_{S}=300,15 \mathrm{~K}$ and environment temperature $T_{e}=280,15 \quad \mathrm{~K}$ when thermodiffusion coefficient [9] $D_{w s}=2.172 \cdot 10^{-2} \mathrm{~m}^{2} / \mathrm{s}$ and time is $100 \mathrm{~s}$. 
The presented profiles of $f(\xi)$ and $P(\xi)$ in Fig. 2 as well as the results presented in Table 1 show that the term $P(\xi)=\frac{1}{2} \xi \cdot f_{l}$ gets small numerical values in the equation (14), and, consequently, can be removed. The linear effects in equations (12), (13) and nonlinear equations (15), (20) can be separated.

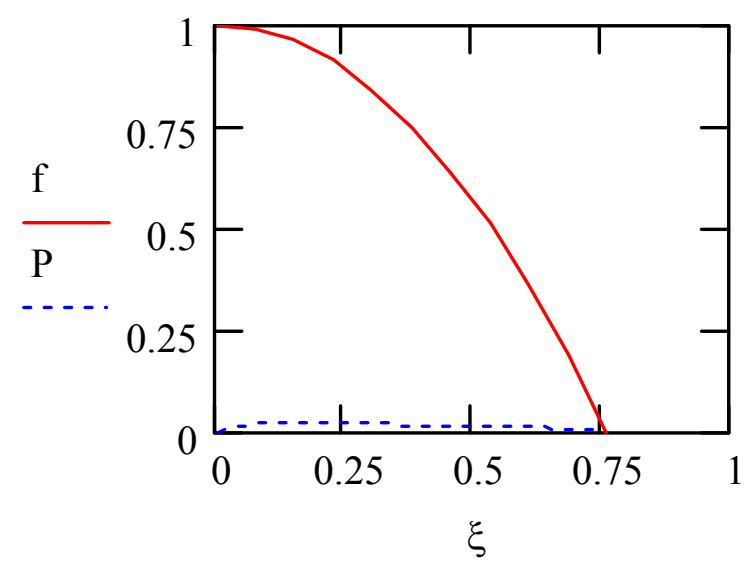

Figure 2. Profiles of nonlinear (16) solution $f(\xi)=\frac{T}{T_{S}}$ and term (14) $P(\xi)=\frac{1}{2} \xi \cdot f_{l}$ for the point source with temperature $T_{S}=300,15 \mathrm{~K}$, environment temperature $T_{e}=280,15 \mathrm{~K}$ when thermodiffusion coefficient [9] $D_{w s}=2.172 \cdot 10^{-2} \mathrm{~m}^{2} / \mathrm{s}$ and time is $100 \mathrm{~s}$.

Concentration profiles (Fig. 3) illustrate the obtained parabolic form of nonlinear equation (16) $f(\xi)=\frac{T}{T_{S}}$ and linear equation (19) $F(\xi)$ solutions.

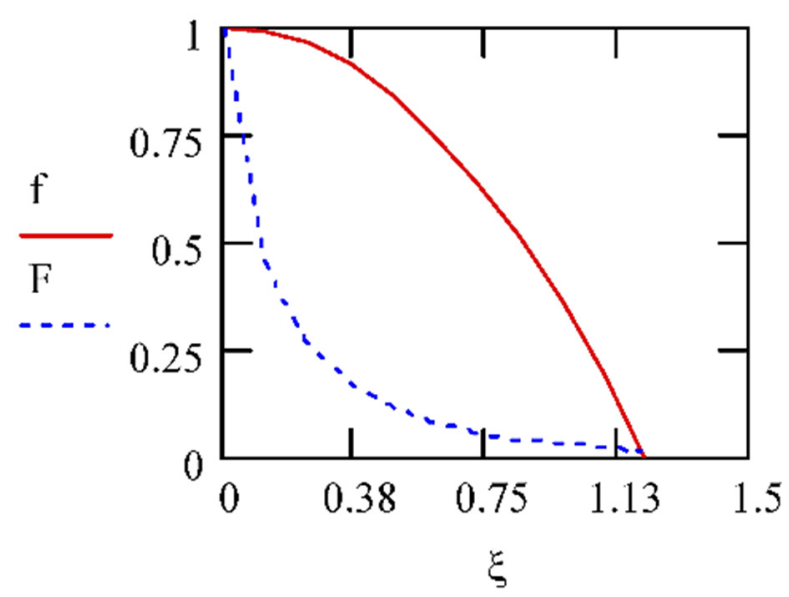

Figure 3. Concentration profiles of nonlinear (16) $f(\xi)=\frac{T}{T_{S}}$ and linear $(19) F(\xi)$ solutions of equations for the point source with temperature $T_{S}=300,15 \mathrm{~K}$, environment temperature $T_{e 0}=250,15 \mathrm{~K}$ when thermodiffusion coefficient [9] $D_{w s}=2.172 \cdot 10^{-2} \mathrm{~m}^{2} / \mathrm{s}$ and thermodiffusion time is $100 \mathrm{~s}$.

It can be explained by taking into account the distribution function [6] of hot molecules with velocities $c$

$$
\frac{\Delta n}{n}=\frac{4 \cdot c_{m}^{3} \exp \left(\frac{-m c^{2}}{2 k T}\right)}{\sqrt{\pi}} \cdot c^{2} \cdot \Delta c
$$

possessing the most probable molecular velocity $c_{m}$ and average velocity $\bar{v}$ [6]

$$
c_{m}=\sqrt{\frac{2 k T}{m}}, \bar{v}=\sqrt{\frac{8 k T}{\pi m}}, \bar{v}=\frac{2}{\sqrt{\pi}} c_{m} .
$$

The average value $\bar{v}$ in (28) must be substituted by the temperature $T=\frac{1}{2} T_{S}$. Gas densities $n$ at this temperature collide with the hottest molecules $2 n_{s}$ when they satisfy the condition $n=2 n_{s}$, which formats the front of temperature. The dependence of density distribution of hot molecules $c_{m}$ and $T_{S}$ can explain the formation of the barrier of hot molecules with greater kinetic energies 


$$
\frac{m c^{2}}{2}=\frac{3}{2} k T
$$

and hot shock waves [11] according (16), (17) and Fig. 4 rapidly spreading in space.

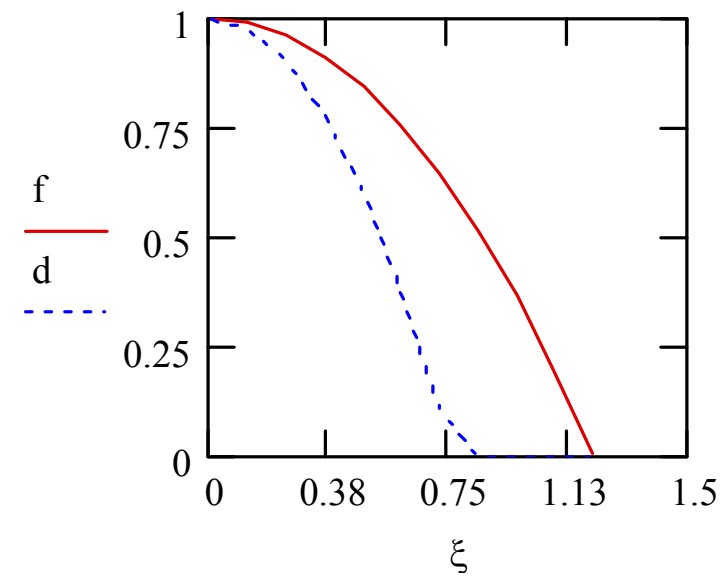

Figure 4. Temperature profiles of functions (16), (17) $f(\xi)=\frac{T}{T_{S}}$ and $d(\xi)$ for the same nonlinear solutions (16) of the point source with temperature $T_{S}=300,15 \mathrm{~K}$, environment temperatures $T_{e 0}=250,15 \mathrm{~K}$ and $T_{e}=280,15 \mathrm{~K}$ respectively for presented temperatures functions $f(\xi)$ and $d(\xi)$ when thermodiffusion coefficient [9] at source is $D_{w s}=2.172 \cdot 10^{-2} \mathrm{~m}^{2} / \mathrm{s}$ for the time interval of $100 \mathrm{~s}$.

In Fig. 4 heat penetration depths (17) from the same source are equal to $r_{e}=2 \sqrt{D_{w s} t} \sqrt{\frac{T_{S}-T_{e}}{T_{S}}}$ and can be similarly explained.

All graphs are presented by using computer algebra system MathCAD.

\section{CONCLUSIONS}

The flow of atoms and molecules by nonlinear diffusion [1] and thermodiffusion is defined by the finite length $\Delta r$ jumps of the hot molecules (4) as well as the finite velocity [1] by using a thermodiffusion coefficient proportional to the temperature (2), (8). The obtained temperature parabolic graphs [11-12] of the nonlinear solutions in Fig. 4 are generated by hot atoms or molecules velocities probability (27), (28) and their dependence on temperature.

The approximate analytical solution of nonlinear thermodiffusion equation for the point source in the spherical case is very complicated and was solved by excluding the linear diffusion equation (13) from the nonlinear equation (12). This can be physically realized only when the third term on the right side of (9) defining diffusion [2] on the frontier $\frac{D_{w n}}{T_{S}}\left(\frac{d T}{d r}\right)^{2}$ is significantly greater than the first term representing the self-diffusion from the source having high intensity of impurities. This can be similar to superdiffusion of impurities by vacancies [13-14] at room temperature in the crystal silicon irradiated with X-rays.

In this case the obtained nonlinear equation (15), solved analytically (16), as can be seen in Fig. 4, by using similarity variables, can be applied with sufficient accuracy.

Nonlinear thermal conductivity in gas [3] was considered in one dimensional case with thermal diffusion coefficient (2) proportional to the gas temperature. Similar equations only for one dimensional case were solved analytically for more complicated thermodiffusion coefficients [15-16] $D=k+m \cdot T^{n}, k>0$ by using similarity variables.

The analytical solution of a more complicated task of nonlinear thermodiffusion equation for a spherically symmetric case by using similarity variable and separation of linear processes has been successfully achieved.

\section{ORCID IDs}

(D) Sigita Turskienè, https://orcid.org/0000-0002-2019-6712

\section{REFERENCES}

[1] A.J. Janavičius, Physics Letters A, 224, 159-162 (1997), https://doi.org/10.1016/S0375-9601(96)00794-3.

[2] A.J. Janavičius, and A.Poškus, Acta Phys. Pol. A, 107, 519-521 (2005), http://dx.doi.org/10.12693/APhysPolA.107.519.

[3] A.J. Janavičius, and S. Turskiené, Proc. of the Lithuanian Mathematical Society, Ser. A, 57, 24-28 (2016), http://dx.doi.org/10.15388/LMR.A.2016.05.

[4] A.J. Janavičius, and S. Turskienè, Acta Phys. pol. A, 110, 511-521 (2006), http://dx.doi.org/10.12693/APhysPolA.110.511.

[5] V.I. Rudakov, and V.V. Ovcharov, International Journal of Heat and Mass Transfer, 45(4), 743-753 (2002), https://doi.org/10.1016/S0017-9310(01)00204-6.

[6] G. Joos, and I.M. Freeman, Theoretical Physics, (Dover Publications Inc., New York, 1986).

[7] A.J. Janavičius, and S. Turskienè, Latvian Journal of physics and technical sciences, 55, 34-42 (2018), https://doi.org/10.2478/lpts-2018-0019.

[8] M.E. Gliksman, Diffusion in solids, (Wiley, New York, 2000), pp. 472. 
[9] L.L Goldin, Laboratory works in physics, (Science, Novosibirsk, 1983). (in Russian)

[10] A.J. Janavičius, G. Lūža, and D. Jurgaitis, Acta Phys. Pol. A, 105, 475-483 (2004), http://dx.doi.org/10.12693/APhysPolA.105.475.

[11] Ya.B. Zeldovich, and Yu.P Raizer, Physics of Shock Waves and High-Temperature, Hydrodinamic Phenomena, (Dover Publications, 2003).

[12] A.J. Baškys, D.J. Zanevičius, O.N. Kolomojec, and A.J. Janavičius, Algebric Devices-Technological Model for production Integral Schemes, Microelectronics Ser. 3, 4(307), 44-47 (1989). (in Russian)

[13] A.J. Janavičius, S. Balakauskas, V. Kazlauskiene, A. Mekys, R. Purlys, and J. Storasta, Acta Phys. Pol. A, 114, 779 (2008), http://dx.doi.org/10.12693/APhysPolA.114.779.

[14] A.J. Janavičius, et al, PCT publication number WO/2014/062045, PCT declaration number PCT/LT2013/000017, Declaration in USA No. 14/436,934 (2016).

[15] C.J. van Duyn, and L.A. Peletier, Nonlinear Analysis: Theory, Methods \& Applications, 1(3), 223-233 (1977), https://doi.org/10.1016/0362-546X(77)90032-3.

[16] V.D. Djordjevic, and Th.M. Atanackovic, Journal of Computational and Applied Mathematics, 222(2), $701-714$ (2008), https://doi.org/10.1016/j.cam.2007.12.013.

\section{МОДЕЛЮВАННЯ НЕЛІНІЙНОЇ ТЕРМОДИФУЗІЇ ДЛЯ СФЕРИЧНО СИМЕТРИЧНОГО ВИПАДКУ Арвидас Й. Янавічюс, Сігіта Турскісне}

Інститут регіонального розвитку, Університет Шяуляй, Литва вул. П. Вішинсько, 25, LT-76351

У статті розглядаються властивості нелінійного рівняння термодифузії, що відповідає процесам теплообміну, які відбуваються з кінцевою швидкістю в газі від джерела високої інтенсивності. У попередніх роботах А. Янавічюс запропонував нелінійне рівняння дифузії, яке надало більш точний опис дифузії домішок за допомогою швидкорухомих вакансій, породжених рентгенівським випромінюванням у кристалах $\mathrm{Si}$. Це $\epsilon$ подібним до теплопередачі в газі $з$ постійним тиском молекулами, які несуть більшу середню кінетичну енергію, на основі нелінійної термодифузії молекул газу з гарячих областей у найхолодніші 3 кінцевою швидкістю випадковими броунівськими рухами. Теплообмін у газі повинен бути сумісним із функцією розподілу Максвелла. Теплопередача в газі описана за допомогою нелінійного рівняння термодифузії 3 коефіцієнтами теплопередачі, які є прямо пропорційними температурі $T$. Рішення рівняння термодифузії в газі було отримано 3 використанням змінних подібності. Рівняння вирішується відокремленням лінійної частини рівняння, яка відповідає другому закону Фіка. Отримані результати співпадають з рішеннями Я. Зельдовича нелінійних рівнянь, що були опубліковані раніше, шляхом зміни відповідних коефіцієнтів

КЛЮЧОВІ СЛОВА: нелінійна термодифузія, джерело високої інтенсивності, рішення подібності, температурні профілі, сферично симетричний випадок 